\title{
Decorative bird as a batik motif, that is inspired by the beauty of a bird's wing flap
}

\author{
M.Faisal Ramadhani ${ }^{1}$, Annisa Indah Aprilia ${ }^{2}$ dan Nanny Sri Lestari ${ }^{3}$ \\ \{ ${ }^{1}$ Goonerfaisal12@gmail.com, ${ }^{2}$ annisaindahapprillia50@gmail.com, ${ }^{3}$ nanny-s1@ui.ac.id\} \\ ${ }^{123}$ Universitas Indonesia
}

\begin{abstract}
Flora and fauna is a buffer for human life. The existence of flora and faunais not only a complement to human life but at the same time can be an inspiration for art for humans. This study discusses various batik motifs associated with bird images. There are many batik motifs that are known by the public. Florals, fauna and objects in general. The focus of this research is to trace one batik motif, the bird motif. Pictures of birds in Javanese batik motifs vary greatly. That way there will be many ways of describing the bird motif in this batik cloth. The purpose of this study is to reveal and explain the cultural messages contained behind the batik motifs with bird pictures. Birds are considered as a symbol of hope for strength, greatness and eternity. This study uses a qualitative research paradigm procedure, because qualitative procedures provide an opportunity for researchers to be able to interpret the data. The results showed that there was one simple concept adopted by the Javanese people in their daily lives. The concept is a concept that seems simple in maintaining harmony, harmony and balance, but how to achieve it is not simple. Through measured observations on each batik motif with a picture of a bird, there is one meaning behind the motif. The meaning of this condition, are the basic of the people's point of view in their daily lives. Besides meaning there is also a message to be conveyed from generation to generation about human life in this world. In addition, through the cultural roots of bird animal symbols, there is a strong link between meaning and message, interlocking with each other.
\end{abstract}

Keywords: prosperity, life, community, birds, culture.

\section{Introduction}

In the perspective of several experts, research on batik has been done a lot. The research was conducted both research on the batik cloth itself and on the matter that is behind the batik cloth. In various batik studies, researchers are more interested in various types of batik motifs. Research on specific batik in particular has not been done much, there are, various studies, but only limited to its physical form. The research was conducted on the basis of many batik fans, especially in terms of batik making. In addition to the interesting aspects of making batik, especially in terms of how to make it unique and also in terms of technical development of decoration. Especially decoration with flora motifs that are very popular with the wider 
community. The flora motif is indeed with all its creative development known by the public as an amazing part. Aside from flora motifs, machete motifs are very dominant in batif motifs [1]. The machete motif seems to be the main motif of Javanese batik. Various kinds of motifs parang batik, widely known by the public, for example parang barong motifs, parang rusak motifs, parang klithik and others. Nowadays there are no singular batik motifs. Many batik motifs are combined and even the name is very interesting. For example sekar Jagat motif, the name alone sounds great.

Apart from batik motifs that are based on flora and also man-made objects, there are also batik motifs that are based on fauna motifs. Fauna motifs are very adapted to the fauna around the Javanese community. Javanese people know many fauna around their environment. The fauna that received the most attention was various types of birds, especially birds and other small flying animals that belong to groups of insects such as wasps, dragonflies, butterflies and others. There are also other animal motifs such as animals such as turtles or other animals but it is not as well-known as the motif of poultry or insects. The motives of poultry such as birds and partridge are very often the motives made by the batik-making community. Bird motifs especially decorate batik cloth from ancient times until now. The bird motif is named according to the wishes of the batik-making community [2].

In Javanese there are many vocabularies related to birds. Starting from the words manuk, kukila, peksi, but Javanese people more often refer to the names of these types of birds such as prenjak, kedasih, kukuk-beluk, emprit, kutut, puter and others. Actually, mentioning the names of these birds shows that Javanese people do know the bird complete with its name. In general, Javanese people keep birds as a means to show prestige because the price of birds is not cheap and maintenance is not easy. In traditional societies raising poultry such as birds is closely related to a number of literary works that indeed require birds as one of the characters in the story. For example in the Ramayana story there is a Jatayu character who is actually a bird, but personified to be able to speak.

This study tries to explore a life concept that is expressed through a variety of decorative batik cloth patterned birds. It is not accidentally that the community displays a bird motif in a piece of batik cloth. This creativity certainly involves so in a cultural message related to human hope and life in its quest for happiness. The concept of life is visually depicted by adopting a bird's body shape. Part of the bird's body which is mainly taken because it gives a very inspiring influence is the flapping of the bird's wings. The flutter of this bird's wings is considered very beautiful from the point of view of the human eye. The flutter of a bird's wings seems to represent strength, power and greatness, something that can be higher than humans but will one day return to its original foothold, namely the earth. This condition is what humans admire from a bird. In reality, on this earth, there are ten species of eagles or eagles that live throughout the world, which have very wide fluttering of wings. This condition is certainly highly admired by humans [3].

Some important research related to the symbolization of birds towards certain viewpoints. Based on research from P. Purwanto et.all [4] who tries to understand the concepts behind the song bird Burung Kutilang finches for toddlers who learn to sing. The emphasis of this research is more on the motivation for personality development contained in the lyrics of the song. Next is the writing from Sarwono et.all [5] which discusses the text of children's songs in helping to introduce children to the environment. This text raises a simple thing that a child under five can understand about his environment. They examines that the meaning of an offering involving poultry (including birds) as an offering. Indeed, the classification of bird animals into groups of birds. But not all birds belong to poultry and also writes about the harmful enemy animals of rice farmers. There is an oral belief among farmers that birds as 
rice-eating animals are enemies of the goddess Sri. The community believes that this rice eater has a group leader who is able to come to the yellowing rice fields to destroy the rice plants. There is also an environmental balance from the perspective of traditional communities. The environmental balance has begun to decline not only because people do not know cultural knowledge but also because people are apathetic or do not care about their environment .

This research is an attempt to explain the views of the Javanese people who are behind the bird decoration on a piece of batik cloth. The decoration of this bird is not always depicted by the physical appearance of the bird, but rather just the wings, because the flap of the wings of the bird is what attracts human attention. In addition to the flutter of birds that are so interesting is the attention of humans, to certain birds that have no form. The bird is an eagle. This eagle is a bird that only exists in myth only. The true form of this eagle, no one knows, but because the name eagle is familiar in Hinduism, the bird has a myth rooted since the influence Hinduism entered the archipelago. From all previous research, all of them discussed the beauty of batik motifs in general. Indeed, no one has discussed a very specific batik motif, especially related to the flapping of bird wings. It turns out that flapping bird wings can be an inspiration for batik makers to create one particular batik motif which is then given the meaning of beauty. The use of bird decoration for various daily uses has actually been happening for a very long time. Birds are known as ancestral spirits who have left the mortal world into the realm of eternity.

This research is an interdisciplinary study of literature, environment and culture. This research began with a deep curiosity for bird decoration in various batik motifs. The decoration as a form of art has a value, meaning and message to be conveyed in full to the public. As a decoration in batik cloth, of course, has values, meanings and messages that are not just a picture. The decoration can be a text about the philosophy behind the decoration.

The meaning of the decoration can not be separated from all the cultural elements that lie behind it. The results of this study complement previous research. One new thing that complements the previous research is the creative idea to give meaning to the flap motif of bird wings adapted to his era. For batik artists, the flap motif of a bird's wing is an embodiment of thinking about the beauty of the natural environment. The same thing happened to the message to be conveyed by the decoration in a cultural context. There is always a link between the meaning contained in the decoration with the message to be conveyed through the decoration.

\section{Research Method}

In conducting a search to find an answer to a series of questions that are in the minds of researchers, researchers collect a number of data. The data is divided into two groups, namely inductive and deductive. The initial step of this research is to do a textual approach, in this case required pictures and information about the concept. The analysis technique uses an interactive work model consisting of three components, namely data reduction, data presentation, and verification. Verification is carried out on a number of opinions on certain concepts or points of view related to culture. This research can be categorized as a qualitative research paradigm procedure because it depends more on the interpretations of researchers . Presentation of data to the object of research is needed to support a critical analysis of the concept or point of view of the people who are related to culture [6]. This research, will also explore the environment, especially the natural environment and social environment of the 
community in the story. Behind the image of such a bird's wing is considered great there is a description of the natural environment and the social environment there, a meaning and message to be conveyed through a piece of batik cloth. Indeed capturing the meaning and message in the batik cloth with bird motifs is not easy. Spawning and explanation and interpretation must be careful because of the accompanying cultural background. The analysis was also carried out by interpreting the cultural symbols contained in the image as a discourse text. Cultural symbols associated with batik cloth with bird motifs. The data in this study are in the form of expressions, phrases, or sentences related to batik cloth with bird motifs that are generally known by Javanese people.

\section{Results And Discussion}

\subsection{Environmental issues in batik motifs}

Batik is a traditional Javanese fashion. Batik has appeal from various angles. Starting from the point of making batik, which are very traditional, and requires very special skills, to the philosophical values behind it. The technique of making batik has indeed been recognized as a technique of making very complicated clothing materials. The batik makers apply a certain way to apply batik techniques that are very traditional. The technique of making batik cannot be separated from the environment of the people who made the batik craft. Therefore, many craftsmen are inspired by the condition of the natural environment that is around their residence [7]. In general, the people raised all sides of the environment around them. Starting from the side of life associated with flora, fauna and nature or earth and human-made objects.

For flora and fauna, batik motifs utilize various types of flora and fauna that are around the community environment. As is well known, the island of Java is located in the tropics, therefore a tropical environment that is rich in plants and various kinds of animals inspires many batik makers to spill their ideas on a piece of cloth. For example batik cloth with a variety of decorative bases - reasons for trying to display the forest with its contents, for example forest plants, interspersed with ornamental varieties of partridges and other small animals, such as birds. But it can also happen that a batik focuses his idea on only one object, for example only flora or fauna. Everything depends on the creativity of the batik [8]. Natural environments such as contemplation and steep coral and clouds in the sky can also inspire batik makers to pour their ideas on a piece of cloth [8]. The uniqueness of the decoration in batik cloth, often seen from its fixed shape, and neat or unchanged from section to section. This condition is inviting admiration when a piece of batik cloth is completed through a process that is quite long. The simplest example when making batik with various decoration slopes, the shape of the slope will be constant from the left starting point to the end point on the right. The thing that must be considered is that the batik makers do not always depict the flora and fauna or natural decoration in accordance with the original but rather the abstract form in accordance with the understanding of community art.

\subsection{Variety of ornamental animals in batik}

Animals are one of the many kinds of ornament known for decorating batik cloth. The variety of ornamental animals is usually depicted on batik cloth not in its original form. Batik makers are usually very inspired by the physical form of these animals, and make batik decoration. There are various decorations whose main theme is birds. The Variety of ornamental birds usually only taken only wings or commonly referred to in Javanese lar/elar. 
There are a number of names for the bird's wing decoration, such as the babon angrem, ayam alas, Bango Buthak, Siddha Luhur, Siddha Mukti, and others in accordance with the wishes of the batik maker. People's fondness for partridge can also be transformed into batik motifs [9]. In batik pesisiran which is much influenced by Chinese culture with a special colour, the most famous bird decoration is the hong bird decoration and peacock decoration. The peacock does have a very special characteristic, because for this peacock taken is a picture of a bird whose tail is blooming and shows its beauty. In the hong that is taken is the foot of this bird which is very level [10]. The variety of bird decorations in coastal communities is very dependent on the interests of the batik artist and the community. In general, a variety of ornamental bird or lar or wing is intentionally made not in its full form. Generally it is made just to show that it is a bird's wing.

\subsection{Meanings and messages on bird wing flap ornamental designs}

Birds are animals that physically have different physical forms from other animals. The advantages of this animal can fly from short distances to long distances. If you look carefully or if you see with the recording of a film, then the flap of a bird's wings looks very beautiful. Especially if a bird is floating in the air, by expanding its wings, it is really a very beautiful sight. As an animal that has its own uniqueness, certainly a bird is a very special animal [17]. There are indeed various types of birds in this nature [11]. In every region of the earth the weather has a different type of bird. This diversity of bird species characterizes the richness of life in the world. In the tropics, biological wealth associated with birds is enormous. In the tropics found various types of birds that have physical characteristics that are very beautiful. This condition is certainly very charming people.

Birds that have a large physique with a very wide wing span, become a special attraction. The bird can influence humans to create mythological creatures like the eagle. On the other hand, birds that actually live in nature such as eagles also inspire people to create an ornamental variety that mimics birds. In batik, the decoration of birds has a strong enough meaning. Bird ornamental variety is not always described by the full physical form of the bird, but often only the wings are taken [12]. The meaning behind this is the bird's wing is a sign for those who see, that the decoration on the fabric is the decoration of birds. Birds for Javanese people are a symbolic form of ancestral spirits who are looking for a way to return to their creator. There is one new thing that can be seen from the lives of Javanese people. Javanese people are observers of the natural environment who are patient and conscientious. The beauty of the flapping of a bird's wing which is regarded by others as something ordinary, for Javanese people, especially batik artists, can be something extraordinary. The beauty evokes creative ideas that are embodied in batik motifs. The synergy of natural beauty with batik motifs and human thought becomes a lasting cultural monument, especially in the meaning that is in it. The message to be conveyed to the public, through this bird wing decoration is that life is not easy. The stretch of a human hand is not enough to measure the ups and downs of human life. All human life is a stretch of life that must be passed through joy and sorrow; therefore face a straight path forward like a bird in flight to achieve something good. 


\section{Conclusion}

The decoration is an expression of the beauty that humans see. Decorative can be made on wood, fabric, stone, metal or anything else. The decoration on the stone can be seen on the stone wall found in Hindu-Buddhist temples in Java, the decoration on the carving on the stone also has various kinds of decoration such as flora and fauna. The most common decoration on metals is the decoration found on the keris. The decoration on the keris is usually on the metal of the keris but there is also a keris handle or the keris holder. In addition, decoration is also found in the keris warangka, because it is made of wood. Decorative types on wood are also found in wood carvings which are usually used to make houses or walls in Javanese, usually known as gebyog. Decorative types on metal are also found on metal inscriptions which are usually used to write royal orders for the position of a territory or a treaty. Decorative types are also found on clay objects or pottery, some are called ceramics (gerabah). These decorative types usually have ceramic objects that are used in everyday life. Other decoration is also found on the fabric, namely batik cloth. The elar ornamentation on batik is usually a decorative ornament that is full of meaning and message. Behind the decoration, there are things to be conveyed.

\section{References}

[1] A. Prasetyo and Singgih, "Karakteristik Motif Batik Kendal Interpretasi dari Wilayah dan Letak Geografis," Imajin. J. Seni, 2016.

[2] A. B. Utami and N. S. Lestari, "FUNCTION, MEANING, AND MESSAGE OF THE NATURAL ENVIRONTMENT IN THE STORY OF KEONG MAS," Int. Rev. Humanit. Stud., 2019, doi: 10.7454/irhs.v4i2.164.

[3] D. Wihardi, R. G.Pratikto, and S. Kristanty, "Pergeseran Makna Motif Batik Yogyakarta Surakarta,” J. Ilm. Komun. Makna, vol. 5, no. 2, p. 105, 2014, doi: 10.30659/jikm.5.2.105-113.

[4] P. Poerwanto and Z. L. Sukirno, "Inovasi Produk dan Motif Seni Batik Pesisiran sebagai Basis Pengembangan Industri Kreatif dan Kampung Wisata Minat Khusus," J. Al-AZHAR Indones. SERI PRANATA Sos., vol. 1, no. 4, pp. 217-229, 2014.

[5] Sarwono and E. Kurniadi, "Structuralism Approach: Symbolism Of Traditional Batik Pattern Of Javanese Traditional Clothes In Surakarta," 2019, doi: 10.2991/reka-18.2018.17.

[6] J. W. Creswell and V. L. Plano-Clark, "Choosing a mixed methods design," Des. Conduct. Mix. Method Res., 2011.

[7] K. Saddhono, S. T. Widodo, M. T. Al-Makmun, and M. Tozu, "The study of philosophical meaning of Batik and Kimono motifs to foster collaborative creative industry," Asian Soc. Sci., 2014, doi: 10.5539/ass.v10n9p52.

[8] J. Bennett, "IIm or fashion? The question of identity in the batik designs of Java," in 'Ilm: Science, Religion and Art in Islam, 2018.

[9] L. Aitken, "Turtle Island: The Story of North America's First People by E. Yellowhorn and K. Lowinger," Deakin Rev. Child. Lit., 2018, doi: 10.20361/dr29338.

[10] S. S. Oparinde, "Batik As a Cultural Identity of the Yoruba: Hand Colouring Techniques and Applications ," J. Arts, Sci. Commer., 2012, doi: 10.1016/j.jhydrol.2015.03.027.

[11] N. Suciati, W. A. Pratomo, and D. Purwitasari, "Batik motif classification using color-texturebased feature extraction and backpropagation neural network," in Proceedings - 2014 IIAI 3rd International Conference on Advanced Applied Informatics, IIAI-AAI 2014, 2014, doi: 10.1109/IIAI-AAI.2014.108.

[12] E. Suprayitno, S. Rois, B. Harmanto, and N. Iman, "Representasi Falsafah Jawa dalam Cerita Rakyat "Terjadinya Terowongan Air Mangge," Madah J. Bhs. dan Sastra, 2018, doi: 10.31503/madah.v9i2.813 
